\title{
A Microsimulation Model to Study the Interaction between Fertility and Union Formation and Dissolution: An Application to Canada and Quebec
}

\author{
Alain Bélanger \\ Centre - Urbanisation Culture Société \\ national de la recherche scientifique (INRS) \\ Montréal, Québec, Canada \\ E-mail: $\underline{\text { Alain.Belanger@UCS.INRS.FD }}$ \\ Jean-Dominique Morency \\ Centre - Urbanisation Culture Société \\ national de la recherche scientifique (INRS) \\ Montréal, Québec, Canada

\section{Martin Spielauer} \\ Statistics Canada - Modeling Division \\ Ottawa, Ontario, Canada
}

\begin{abstract}
Union formation and dissolution are among the main determinants explaining variations in fertility. Compared to the rest of Canada, Quebec's marital histories are more complex and its prevalence of common-law unions much higher. The objective of this article is to examine the role of marital behaviours on fertility by comparing different indicators of fertility and conjugal life that were obtained through microsimulation. Parameters of the microsimulation model were estimated from hazard regressions performed on the marital and fertility histories collected in two retrospective longitudinal surveys: the Canadian General Social Survey (GSS) 2001 and 2006. Results show that the more complex marital histories of Quebecers can explain more than one-quarter of their fertility differences with the rest of the country.
\end{abstract}

Key Words: Fertility, marriage, cohabitation, Quebec and Canada, microsimulation 


\section{Résumé}

Les formations et dissolutions de couples comptent parmi les déterminants majeurs qui expliquent les variations dans le taux de fécondité. Comparé au reste du Canada, les antécédents matrimoniaux des Québécois sont plus complexes et les unions de fait y sont beaucoup plus nombreuses. L'objectif de cet article est d'examiner le rôle que jouent les comportements matrimoniaux sur la fécondité en comparant différents indicateurs sur la fécondité et la vie conjugale qui ont été obtenus par microsimulation. Les paramètres $d u$ modèle de microsimulation ont été évalués par des régressions de risques que nous avons menées sur les historiques de fécondité recueillies lors de deux enquêtes longitudinales rétrospectives : l'Enquête sociale générale (ESG) 2001 et 2006. Les résultats démontrent que les antécédents matrimoniaux plus complexes des Québécois peuvent expliquer plus d'un quart de leurs différences de fécondité avec le reste du pays.

Mots-clés: Fécondité, mariage, cohabitation, Québec et Canada, microsimulation

\section{Introduction}

Over the past few decades, Canadian union formation and dissolution have witnessed rapid and important changes. Until the end of the 1960's, marriage was almost universal, and common-law unions and divorces were rare (Dumas and Péron 1992). Most people married early in life and remained married until either death or widowhood. In the following decades, the prevalence of common-law unions increased rapidly, first as a prelude to marriage, but soon as a substitute to marriage and remarriage. At the same time, legal changes regarding formal unions resulted in increasing number of divorces and shorter durations of marriages, while common-law unions remained less stable than marriages. As a result, marital histories became much more complex as average union durations diminished and the number of unions lived by an individual during his lifetime increased (Statistics Canada 2002). These changes in conjugal life affected all Canadian provinces but were more pronounced in the province of Quebec than elsewhere (Juby et al. 2004; Statistics Canada 2002; Laplante 2004; Le Bourdais and Marcil-Gratton 1996; Belliveau and Oderkirk 1994). 
A Microsimulation Model to Study the Interaction between Fertility

and Union Formation and Dissolution: An Application to Canada and Quebec

At the same time that these changes in conjugal life in Canada were taking place, fertility declined rapidly, going down from 4.0 children per women at the peak of the baby boom to around 2.0 children per women about a decade later in 1970 (Romaniuc 1984). Fertility has continued to decline and since the beginning of the new millennium, total fertility rates have oscillated around 1.55 children per women (Bélanger 2006). This decline is generally explained by several social and economic changes: increasing availability and acceptability of reliable contraception methods, increasing female education level and labour force participation, but also declining popularity of marriages and increasing conjugal instability (Beaupré and Cloutier 2007). Union formation and dissolution are among the main determinants explaining variations in fertility (Bongaarts 1978) and as cohabitation becomes more prevalent, it can affect overall fertility (Wu 1996). Having a child is a long-term commitment and so the precariousness of unions can be a factor that reduces completed fertility below the desired number of children.

This paper examines the role of differences in marital behaviours on fertility by comparing different indicators, such as completed fertility rates, parity distributions and average number of years lived in different conjugal states, that were obtained through microsimulation. The fertility and conjugal histories of women born after 1955 are used to estimate the parameters of a model that yields indicators that are not easily available in Canada, such as the proportion of childless women or the average number of years lived in each conjugal state (including common-law unions). The evolution of conjugal life has differed significantly in the province of Quebec compared to the rest of Canada (Statistics Canada 2002; Lapierre-Adamcyk et al. 1999; Bélanger and Dumas 1997); accordingly, the analysis is performed separately for these two regions and a special simulation attempts to measure the effect of the differences in conjugal life of Quebecers on completed fertility.

The first part of this paper briefly reviews recent trends in union formation and dissolution. It is followed by a methodological section that describes the data source, the microsimulation model and the estimation of the model's parameters. The third section presents the results of the simulations and is followed by a discussion and a conclusion.

\section{Trends in Union Formation and Dissolution}

In Canada, the annual number of marriages reached a maximum at 200,500 in 1972 and has generally been declining since then. In 2003, the latest year for which vital statistics on marriages are available, 147,400 
marriages were recorded (Statistics Canada 2008). While most marriages ended, up until the end of the 1960's, by the death of one of the spouses, the adoption in 1968 of a new law on divorce (that mirrored changes in values and beliefs in the population) resulted in a rapid increase in the number of divorces. From a few thousand per year in the years preceding the law, the number of divorces peaked at 96,200 in 1987, a figure resulting mostly from the modifications to the law that were implemented in 1986. The number of divorces declined thereafter and have stabilized at around 70,000 a year since 1998. The total divorce rate, a measure of the proportion of a marriage cohort ending by divorce, has averaged a little more than $35 \%$ since 1981, with annual fluctuations that reflect changes more in the tempo than in the quantum of the phenomenon.

In Quebec, the decline of marriage is even more pronounced. While 53,800 marriages were performed in the province in 1972, this number had dropped by 2003 by more than one half to only 21,100 . Quebec showed the lowest total first marriage rate of all provinces: 300 per thousand for males and 330 per thousand for females. (These numbers compared to 485 and 510 per thousand for males and females, respectively, in all of Canada (Statistics Canada 2006).) Not only are marriages less frequent in Quebec than in the rest of the country, but they are also less stable. The total divorce rate has fluctuated around $50 \%$ since 1987 (Girard 2008).

Whereas marriage is much less prevalent in Quebec, the differences are less important when we look at the proportion of the population living in conjugal unions. According to the 2006 Canadian Census, the proportion of the population aged 15 and over living in a union is $57.6 \%$ in Quebec, a number comparable to the $59 \%$ observed in the rest of Canada. The largest difference between Quebec and the rest of the country resides in the type of union that people choose. Commonlaw unions are much more popular in Quebec than in the rest of the country. The Census also shows that while $35 \%$ of the population living in a conjugal union are in common-law unions in Quebec, this proportion is only of $13 \%$ in the rest of the country (Girard 2008). This larger appeal of common-law unions in Quebec can also be related to the fact that union formation is also occurring at a younger age in that province. Among women aged 25 to $29,59 \%$ are living in a union in Quebec, while this percentage is $53 \%$ in the rest of the country.

Vital statistics do not provide information on common-law union formations and dissolutions; thus, we have to rely on survey data. Since fertility and marital histories were made available in Canada from retrospective longitudinal surveys (Canadian Fertility Survey of 1984 and the General Social Surveys of 1990, 1995, 2001 and 2006), union formations and dissolutions and fertility have been studied extensively 
A Microsimulation Model to Study the Interaction between Fertility

and Union Formation and Dissolution: An Application to Canada and Quebec

using survival analysis and hazard models (Burch and Madan 1986; Balakrishnan et al. 1993; Bélanger and Dumas 1997). Bélanger and Turcotte (1999) analysed the effects of socio-demographic characteristics on the formation of a first union in Quebec, including the effect of a previous birth on the risk of forming a common-law union or a marriage. $\mathrm{Wu}(1995)$ analysed the role of children on the stability of cohabitation relationships and Le Bourdais et al. (2000) studied how the more rapid progression of common-law unions in Quebec, compared to the rest of the country, has affected the risk of separation in families with children. However, rarely has the reverse relationship--how fertility could have been affected by changes in conjugal unions--been studied comprehensively. As expected, childbearing has been found to be positively associated with union stability (Steele et al. 1995). Loomis and Landale (1994) and Manning (1995) found that the fertility of American cohabitating couples was lower than that of married couples. Wu (1996) studied the timing of a first birth in Canadian common-law unions and found that the higher fertility of common-law unions in Quebec, compared to the rest of Canada, remained in place, even after controlling for other socio-demographic characteristics.

In an introductory article to a special issue of Cahiers québécois de démogaphie devoted to common-law unions, Lapierre-Adamcyk and Charvet (1999) concluded their review of what has been done and what is left to do by enumerating a list of subjects that have not yet been studied. The effect of common-law unions on the durability of unions and fertility is the first subject on the top of their list. Thompson et al. (2009) studied the relationship between union instability and fertility in France. They postulated that although "unstable unions can have a negative effect on fertility, union dissolution also produces a pool of persons at risk of new partnership and further childbearing. And when the dissolved partnerships have already produced children, new partnerships have the potential to produce more children than would have been born had the first parental union remained intact" (Thompson et al. 2009: 2-3). To study the net effect of union instability on fertility, they simulated union formations and dissolutions and fertility in France for different cohorts and concluded that the net effect was to reduce completed family size. Their study, however, did not distinguish between types of conjugal unions (cohabitations versus marriages) and modelled only the first and last unions.

This paper is a first attempt to fill in the gap mentioned by Lapierre-Adamcyk and Charvet in a Canadian context by comparing simulated fertility by conjugal histories in Quebec and the rest of Canada. To achieve this, we take a microsimulation approach similar to Thompson et al. (2009), but add to it by including the full conjugal 
history (up to four unions) and by making a clear distinction between the types of conjugal unions.

\section{Data Sources and Methods}

Parameters of the microsimulation model were estimated from hazard regressions performed on the marital and fertility histories collected in two retrospective longitudinal surveys on family transitions: the Canadian General Social Survey (GSS) cycles 15 and 20 (Statistics Canada 2002 and 2007). Records from the two public data files were combined to increase the sample size and reduce the variance of the estimated parameters. It was relatively easy to harmonize the two files, as similar questions were asked in both surveys. We are aware that two surveys measuring the same variables at different points in time may actually measure slightly different things (Korn and Graubard 1999), but we believe that the short time interval between the surveys and the type of information we used (date of birth, date of union formation and dissolution, type of union) minimize the risk of measuring different things in this case. In addition, the two surveys shared the same objectives, and the structures of the questionnaires were very similar, reducing even more the risk that the same question measured different things at two separate points in time.

On the other hand, an advantage to merging the data files is that it doubles the sample size and increases the precision of the estimates. Cycle 20 of the GSS interviewed 23,608 people living in one of the 10 Canadian provinces between June and October 2006 and cycle 15 collected information from 24,310 people in 2001. The 2006 survey represents $49.3 \%$ of the total sample size while the 2001 survey covers the remaining $50.7 \%$. The sample size of both surveys being about the same, we did not adjust the weights before estimating the model's transition parameters.

Both surveys are representative of the Canadian population aged 15 and over living in private households, excluding residents from the northern territories, and were performed by telephone. Among other family transitions, they collected detailed retrospective data on fertility histories of respondents and on union formations and dissolutions. The age at formation and dissolution of up to four marriages and four common-law unions were recorded. The surveys also collected the mother's age at birth for each child (to a maximum of eight children).

We restricted our sample to women born after 1955 and looked at conjugal and fertility events that occurred while they were aged between 15 and 50. Only the oldest cohorts of this sample had effectively 
A Microsimulation Model to Study the Interaction between Fertility

and Union Formation and Dissolution: An Application to Canada and Quebec

completed their fertility when the 2006 GSS was in the field. While there are few observations for marital and birth events at older ages, we believe this has a limited impact on the reliability of the simulation results because fertility is fairly low beyond age 40. The cohort born in 1955 reached age 15 in 1970 and is thus also the oldest cohort to have lived its entire fertile period when divorce and common-law unions were more prevalent and when the total fertility rate was below replacement level.

In total, the marital and fertility life histories of 14,488 women were used to estimate the parameters of the microsimulation model: 2,716 living in the province of Quebec and 11,772 living in the rest of Canada. While all of these women were at risk of experiencing a first union or a first birth, the population at risk of experiencing higher order events was much smaller. Figure 1 schematically describes the conjugal trajectories of the studied population. The numbers in the boxes represent the observed sample size at risk of experiencing the next marital event; the percentages along the arrows represent the proportion of that population at risk that experienced the transition between the two states linked by the arrow.

As an example, looking at the panel of Figure 1 that represents the transitions for the rest of Canada's population, we can see that almost one-third of the 11,772 women born after 1955 had a first common-law union before the date of the interview; a slightly larger proportion (34\%) were married directly. Of the 3,728 who had a first common-law union, $44 \%$ transformed that union into formal marriage while $37 \%$ dissolved their first common-law unions. Adding the number of women who married directly to those who transformed their first common-law union into marriage, a total of 5,693 married women were obtained, who were then at risk of experiencing a divorce. A little more than one- quarter of them did in effect experience a divorce before the date of the interview; adding them to the $37 \%$ of women whose first common-law unions dissolved gives the total of 2,862 women out of a first union who then became at risk of experiencing a second union (and so on for subsequent unions and dissolutions). All of these transitions are simulated in our model.

From Figure 1, one can see that this model treats union formation as a competing risk between the formation of a common-law union and a marriage. Common-law unions are also subject to competing risks as they can be either transformed into formal marriage or dissolved. We also see that our model is rank-specific; transitions between first, second, third and fourth unions (as well as dissolutions) are treated separately. We do not distinguish, however, the type of previous union among those who are out of union and at risk of forming a union of higher rank. The main reason for this is not the difficulty of creating a microsimulation 
model that would take past marital history into account more precisely, but rather the fairly rapid decrease in the sample size of the population at risk of experiencing a higher order event. For example, of the 11,772 single women in the rest of Canada at risk of experiencing a first union, 2,862 women in the studied sample were at risk of experiencing a second union, 499 a third union and only 98 a fourth union. The respective numbers for Quebecers were, of course, even smaller.

Turning now to a more substantive description of Figure 1, important differences are noted between the marital behaviour of the population of the two regions. First, the proportion of women opting for a common-law union is much larger among the Quebec subsample than among the rest of Canada subsample. In Quebec, more than $50 \%$ of those at risk of forming a union of any given $\operatorname{rank}^{1}$ before age 50 formed a common-law union, while in the rest of Canada, this proportion never exceeded $40 \%$. Second, among those who formed a common- law union, the probability that the union turned into marriage was much larger in the rest of Canada than in Quebec. In the rest of Canada, around $40 \%$ of common-law unions of any given rank were a prelude to marriage, while in Quebec, these proportions were much smaller (26\% for the first union, $17 \%$ for the second and only $12 \%$ for the third). Dissolution rates were also larger in Quebec compared to the rest of Canada, both for common-law unions and for marriages. As a consequence, a larger proportion of Quebecers experienced second and third unions compared to other Canadians - $25 \%$ of Quebecers in the studied cohort had a second union compared to $16 \%$ in the rest of Canada; for the third union, these percentages were $6 \%$ and $3 \%$ respectively.

\section{Estimation of Model Parameters}

Before running the microsimulation, we needed to estimate parameters that would then be placed into the microsimulation model. For most events simulated in the model, we first estimated a base risk using a piecewise constant exponential model, and then relative risks using Cox regressions (Cox 1972). The principle behind this approach consists of estimating the distribution parameters over successive short time intervals. The risk is therefore decomposed into a series of exponential distributions (Le Goff 2003). By multiplying the base risk times the relative risk, we could derive probabilities that a person changes states. 
A Microsimulation Model to Study the Interaction between Fertility and Union Formation and Dissolution: An Application to Canada and Quebec

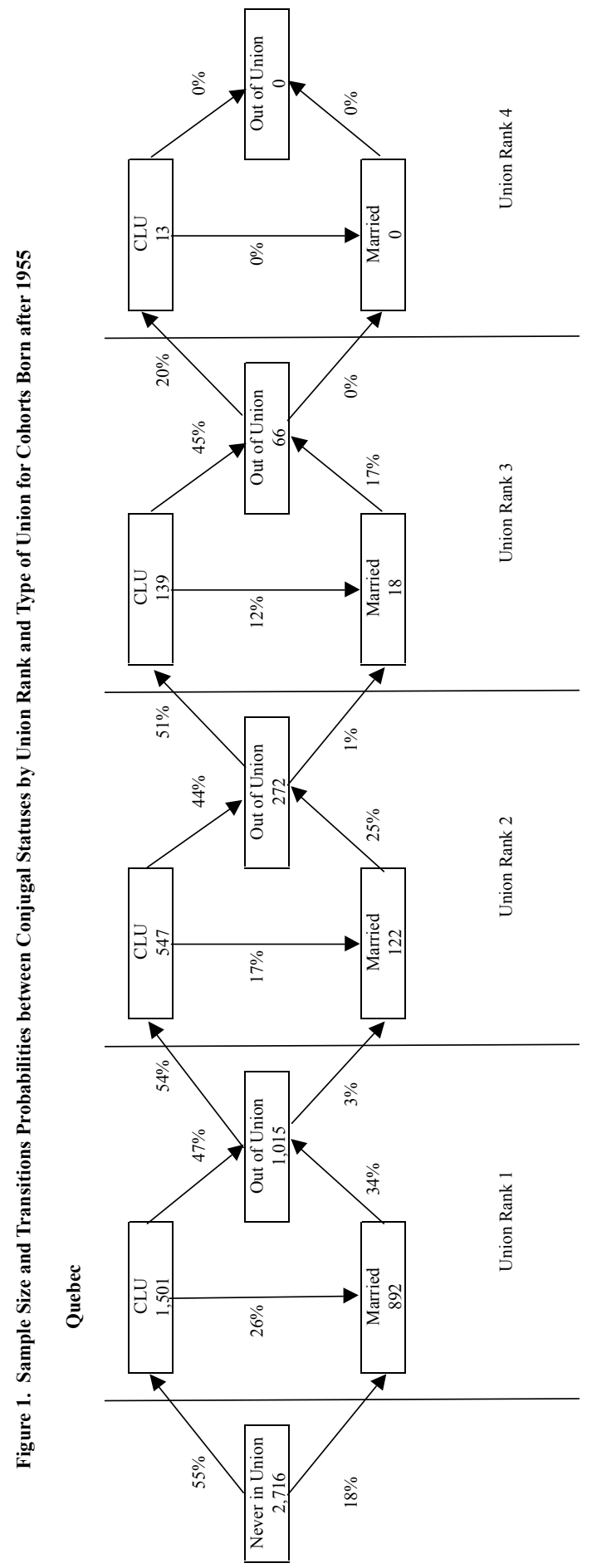

CSP 2010, 37.3-4: 339-373 


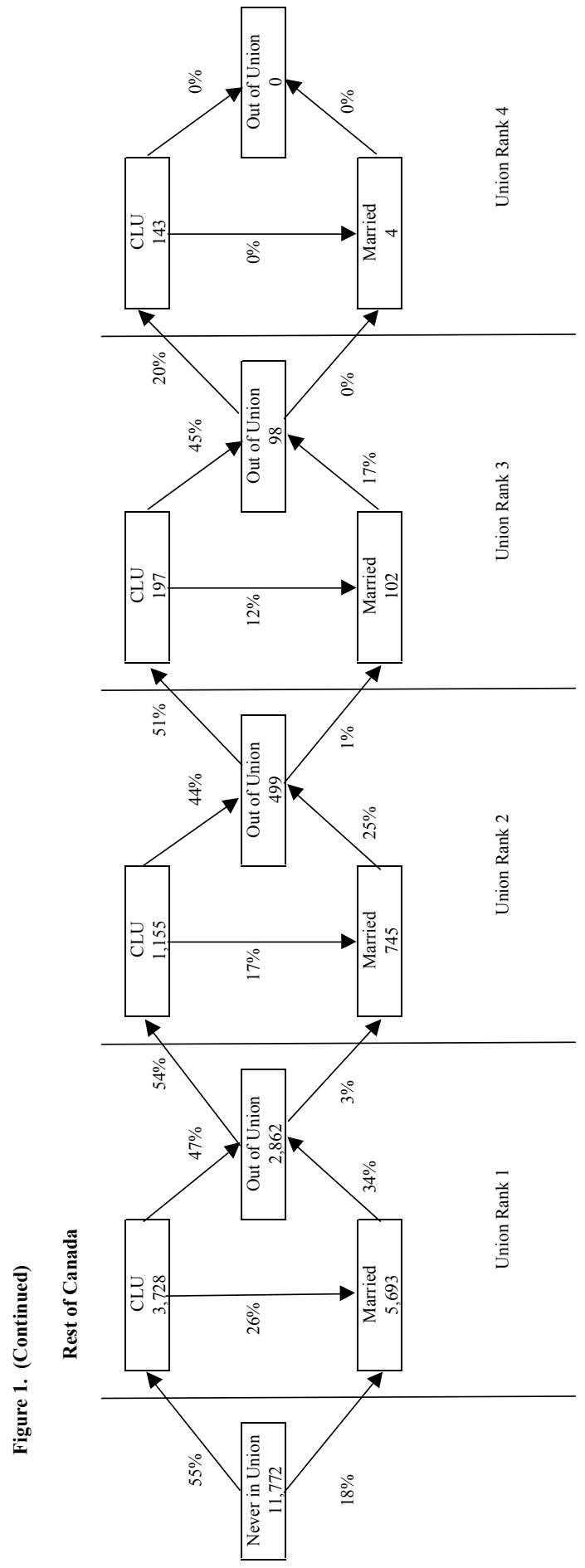

CSP 2010, 37.3-4: 339-373 
A Microsimulation Model to Study the Interaction between Fertility

and Union Formation and Dissolution: An Application to Canada and Quebec

For example, to estimate the base risk of having a first birth, we applied the piecewise constant exponential model to women of the reference category, i.e., those who were married and in their first union. To obtain the relative risks, we then estimated a second model using a Cox regression. This time, we retained individuals of all subgroups, keeping married individuals in their first union as the reference subgroup. However, in some cases the assumed proportionality of the base risk over time was not respected, and so age- or duration-specific rates were estimated from distinct piecewise constant exponential models.

\section{Union Formation and Dissolution}

Parameters were estimated separately for each union rank. Union formation was treated as a competing risk, as women who were single or out of union could choose either to marry or to form a common-law union. The base risk of first union formation started at age 15 while the time origin for the risk of forming a second or higher rank union was the end of the preceding union. First union formation was thus age-specific while second and higher order union formations were duration-specific. We also estimated a relative risk measuring the impact of having had versus not having had a child on the risk of entering or re-entering a union.

Figures 2 and 3 show the estimated union formation rates by type of union for first and second unions, contrasting the rates for Quebec with those for the rest of Canada. The differences in first union formation between the two regions are clear - there are much higher common-law union formation rates in Quebec, particularly at younger ages, and higher marriage rates, particularly after age 20, for women living in the rest of Canada. Similar comments can be made regarding second union formation rates, but we note that the differences between the two regions in common-law union formation rates are less important than for first unions. Quebec's rates for second, third, and fourth unions remain higher than for the rest of Canada - but only by at most $50 \%$-while for many age groups, Quebec's first common-law union formation rates are double the respective rates for the rest of the country. Note also that for the rest of Canada, first marriage rates are generally higher than first commonlaw union formation rates, but for second unions, the risk of forming a common-law union is higher than that of marrying, particularly when there has been a shorter duration since the first union dissolution.

The base risks for union dissolution were estimated using the piecewise constant exponential model applied to the duration since union formation. Rates were calculated separately for each union rank for 


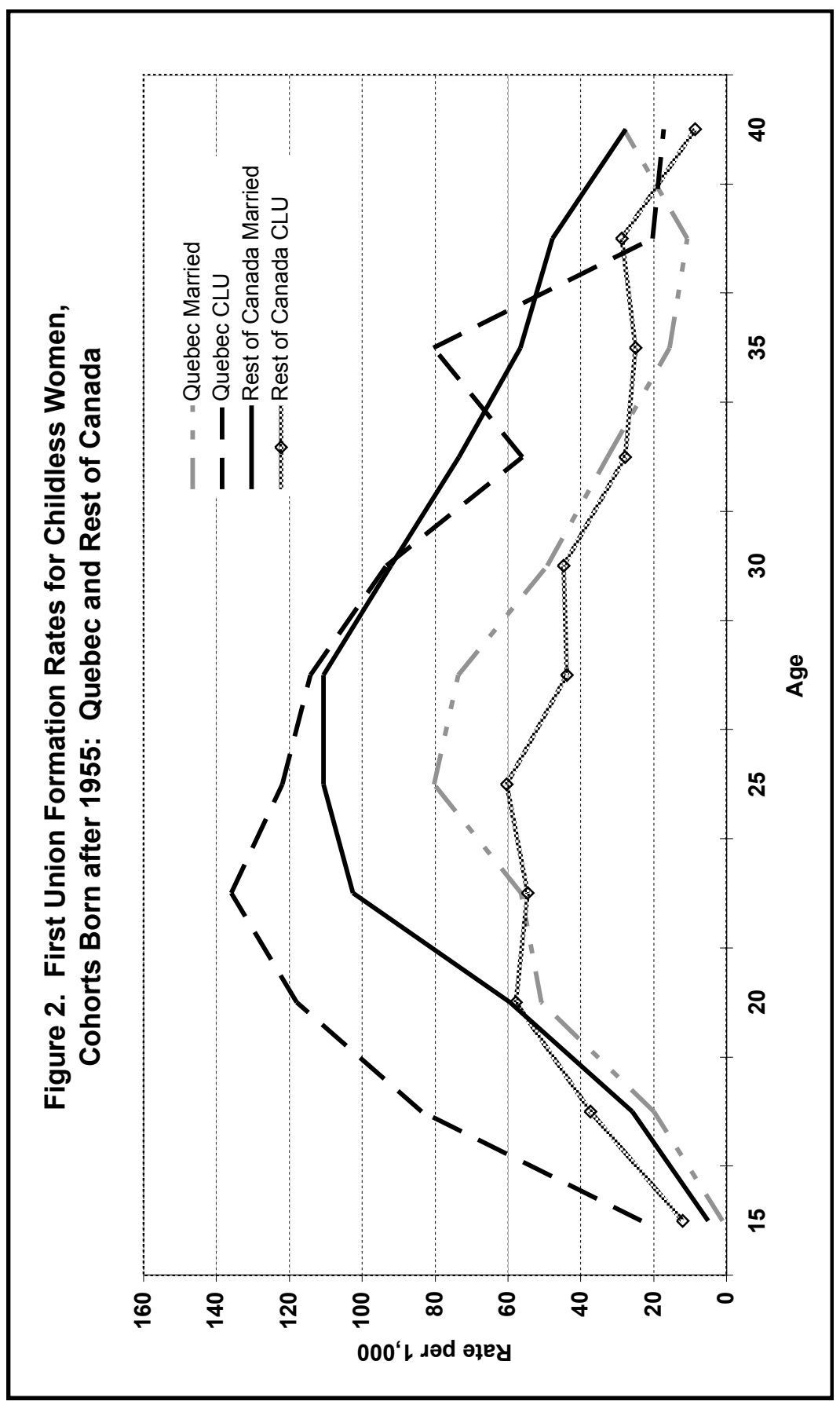

CSP 2010, 37.3-4: 339-373

350 
A Microsimulation Model to Study the Interaction between Fertility and Union Formation and Dissolution: An Application to Canada and Quebec

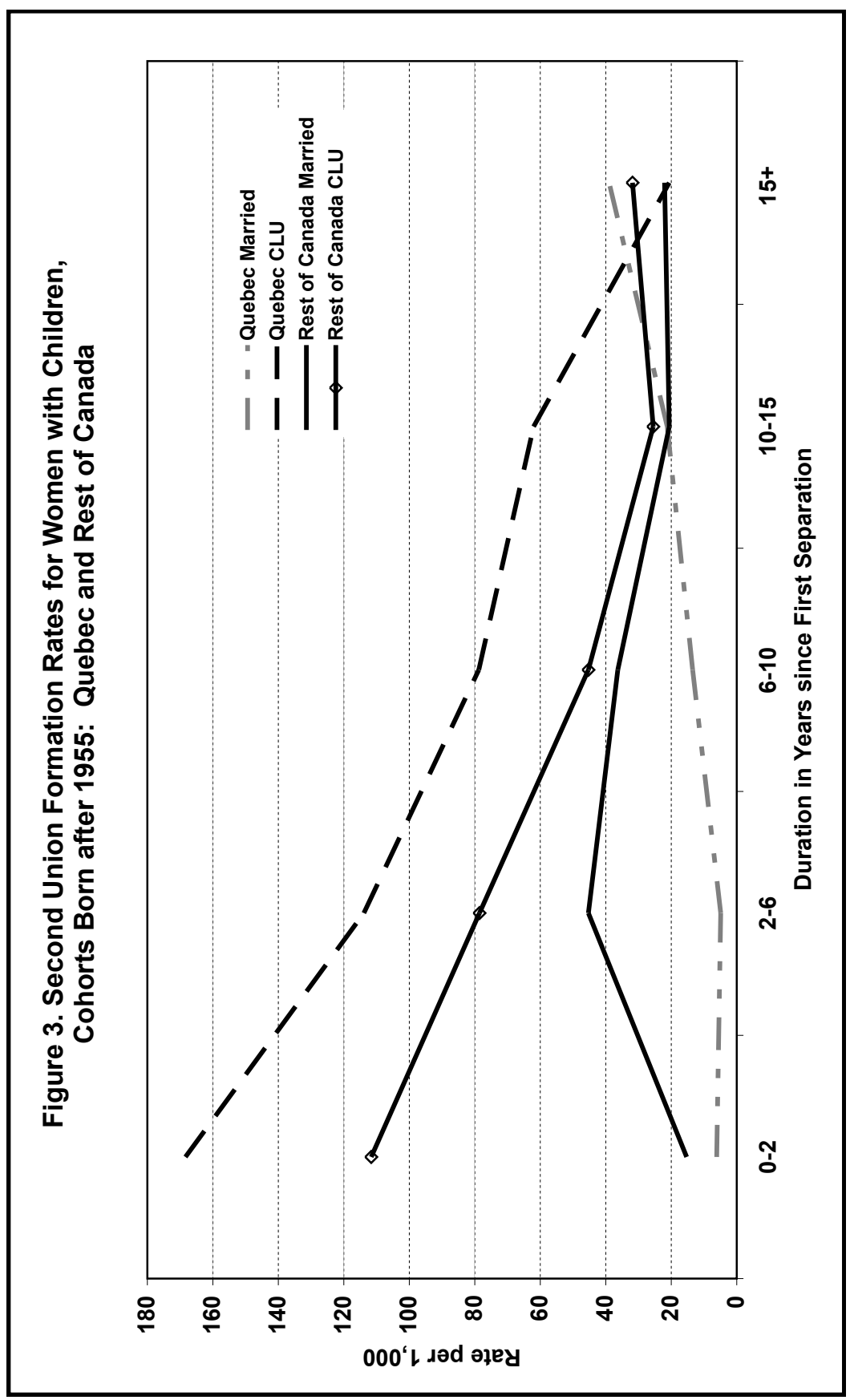

CSP 2010, 37.3-4: 339-373

351 
common-law unions and marriages; a relative risk took into account the effect of having had versus not having had a child on the dissolution rate.

\section{Fertility}

As with union formations and dissolutions, estimated fertility parameters were rank- specific. The risk for a first birth was age-dependent, while it was duration-dependent for second and higher order births. In addition to age or duration since previous birth, estimated fertility rates varied by conjugal status (single, in a common-law union, married, or out of union).

Figure 4 compares estimated age-specific first birth rates for married women and for women in common-law first unions. As expected, the fertility rates of married women are higher than those of women living in common-law unions. Interestingly, rates for both types of unions are higher in Quebec than in the rest of Canada. Yet, results of the simulation show higher childlessness rates in Quebec. This apparent contradiction is another illustration of Simpson's paradox. The explanation of this phenomenon lies in the distribution of couples by conjugal status: a greater proportion of couples in Quebec choose to live in common-law unions than their counterparts of the rest of Canada, and age-specific fertility rates of women in common-law unions are lower than those of married women.

\section{The Microsimulation Model}

To study the impact of fertility and marital behaviour variations we developed a microsimulation model by modifying and expanding the RiskPaths $^{2}$ model first developed by Spielauer et al. (2007) to study the decomposition of the fertility decline observed in Russia and Bulgaria from just before until ten years after the political and economic transitions of the late 1980's in those countries. The program code is written in Modgen ${ }^{3}$, a generic microsimulation language developed by Statistics Canada. Our microsimulation model is a continuous time eventbased competing risk model that generates synthetic cohort fertility and marital histories. It allows for all possible paths that an individual's history can follow. Accordingly, not only can we study the effect of changes in conjugal union on fertility, but also we can study the impact of having had or not having had a child on the risk of entering or reentering into a union. The results presented in the following section are extracted from these histories and can be interpreted as cohort life table indicators coming from a fairly large age-, duration- and rank-specific 


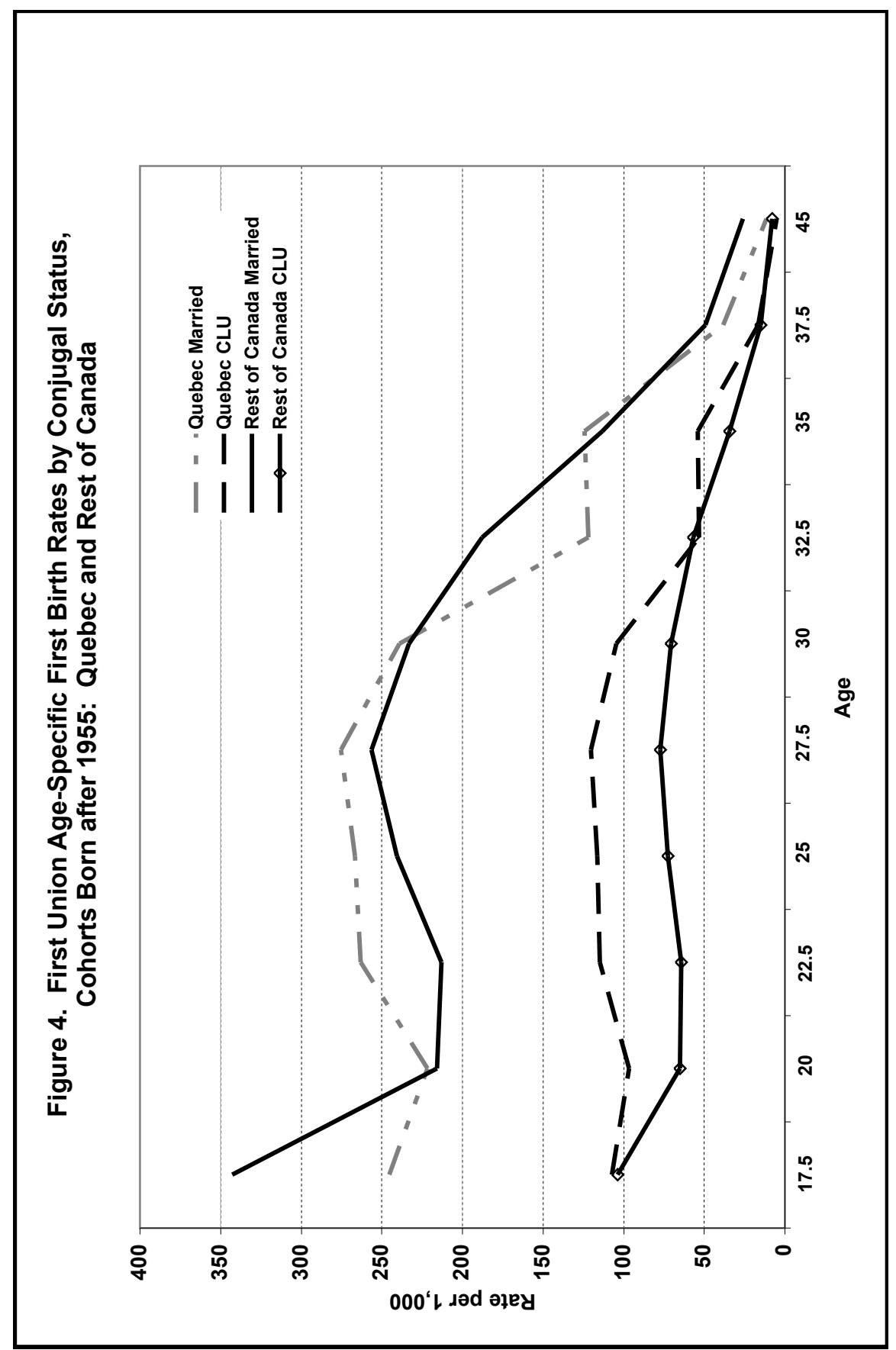

CSP 2010, 37.3-4: 339-373 
multi-state life table where the state space counts for four marital statuses, four union ranks and four birth ranks.

\section{Results}

This section presents the main results of our simulations. First we present the results related to fertility, then those about union formation and conjugal status, and finally those linked to the interaction between fertility and conjugal status.

\section{Fertility}

As expected, the simulated completed fertility of cohorts born after 1955 is greater in the rest of Canada than in Quebec. On average, simulated women in the rest of Canada bear 1.90 children in their lifetime while Quebecers have 1.65 children (see Figure 5). These numbers almost match the average completed fertility rates obtained from vital statistics ${ }^{4}$ for the cohorts born between 1955 and 1975 (1.84 and 1.65 children per women, respectively). This is an indication that our microsimulation model reproduces fairly well the fertility behaviour of the cohorts under study, at least at the aggregate level.

Looking at cumulated fertility over age, we note that the fertility behaviour of women in the two groups is almost the same before age 30 . Thus, for the cohorts born after 1955, the 0.25 child difference in completed fertility is explained by the lower fertility of Quebecers beyond age 30 . Simulated fertility rates by age follow the same pattern for the two groups. Cohort fertility rates peak at age 27 in Quebec and a year later in the rest of Canada; they decrease constantly thereafter, but faster in Quebec than in the rest of Canada.

The microsimulation model allows for the breakdown of the simulated completed fertility by birth rank, a statistic difficult to obtain in Canada, particularly since 1991 which was the final year that the Canadian Census asked a question on the number of children ever born. Figure 6 shows the distribution of simulated women by the number of children to whom they gave birth during their reproductive years. Both in Quebec and in the rest of Canada, the modes of the simulated cohorts are two children--35\% of the women living in Quebec and 37\% percent of the women living in the rest of Canada can expect to have exactly two children. Although a family of two children appears to maintain some appeal among these cohorts, we note that it is probably less and less the norm. Differences in fertility between the two regions result in smaller 
A Microsimulation Model to Study the Interaction between Fertility and Union Formation and Dissolution: An Application to Canada and Quebec

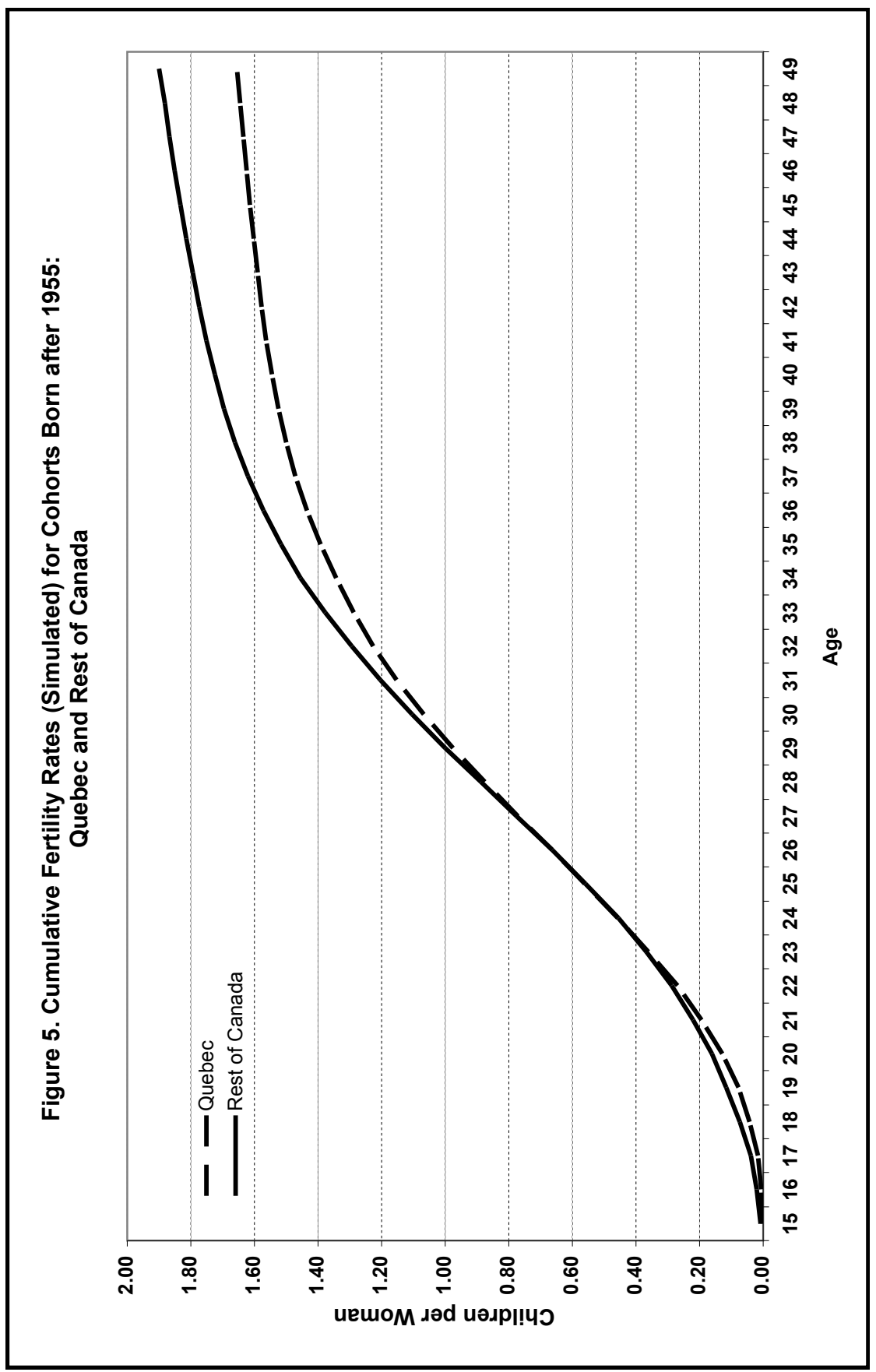

CSP 2010, 37.3-4: 339-373 
family sizes in Quebec compared to the rest of Canada. A little more than a quarter $(27 \%)$ of the women of these cohorts living in Quebec will remain childless, a proportion that reaches $24 \%$ in the rest of the country. A significantly larger proportion of Quebecers born after 1955 will have only one child (18\% versus $13 \%$ in the rest of Canada), and a significantly larger proportion of non-Quebecers will have three children or more ( $27 \%$ versus $19 \%$ in Quebec).

Figure 7 shows the distribution of births by conjugal status for all birth ranks and union ranks. The most interesting observation revealed by Figure 7 is the proportion of births from single mothers who never experienced a union. According to our simulation, in the cohorts born after 1955, approximately $9 \%$ of the births of women from the rest of Canada, compared to 5\% in Quebec, are from mothers who were never in a union. The four percent difference between the two populations could be due to earlier first unions for Quebecers, particularly earlier first common-law unions (Le Bourdais et al. 2000). On average, women from the rest of Canada remain in the never-in-union (single) state more than two years longer than Quebecers. In our model, women who had a union of any type (common-law or marriage) are no longer in the single state after separation, but move to the out of union state. Since common-law unions are less stable than formal unions, a larger proportion of young women therefore move more rapidly into the out of union state in Quebec. This can also explain the larger percentage of births in the out of union state in Quebec compared to the rest of Canada. Therefore, it might be preferable to look at the proportion of births by women not living with their child's father (i.e. never in union + out of union). These percentages reach $11 \%$ and $13 \%$ in Quebec and the rest of Canada, respectively. At first glance, these percentages may appear fairly large, but other studies confirm that an increasing proportion of births are occurring to mothers who were not living with their child's father. Juby et al. (2004), analyzing data from the National Longitudinal Survey of Children and Youth (NLSCY), found that the percentage of children born from single mothers increased from less than 6\% in 1983-84 to $10 \%$ in $1997-98$.

Another interesting result is the percentage of births taking place in couples living in common-law unions. In the simulated cohorts, nearly $37 \%$ of births occurring in Quebec take place in this kind of union, compared to $11 \%$ for the rest of Canada. Births from common-law unions, which are still marginal in the rest of Canada, are now very frequent in Quebec. As a corollary, many more births are taking place in marriages in the rest of Canada than in Quebec (75\% versus 52\%). These results reflect the different perceptions of those in common-law unions in the two regions. While a common-law union is more and more a substitute for marriage and marriage is less and less a necessity for 
A Microsimulation Model to Study the Interaction between Fertility and Union Formation and Dissolution: An Applicatio to Canada and Quebec

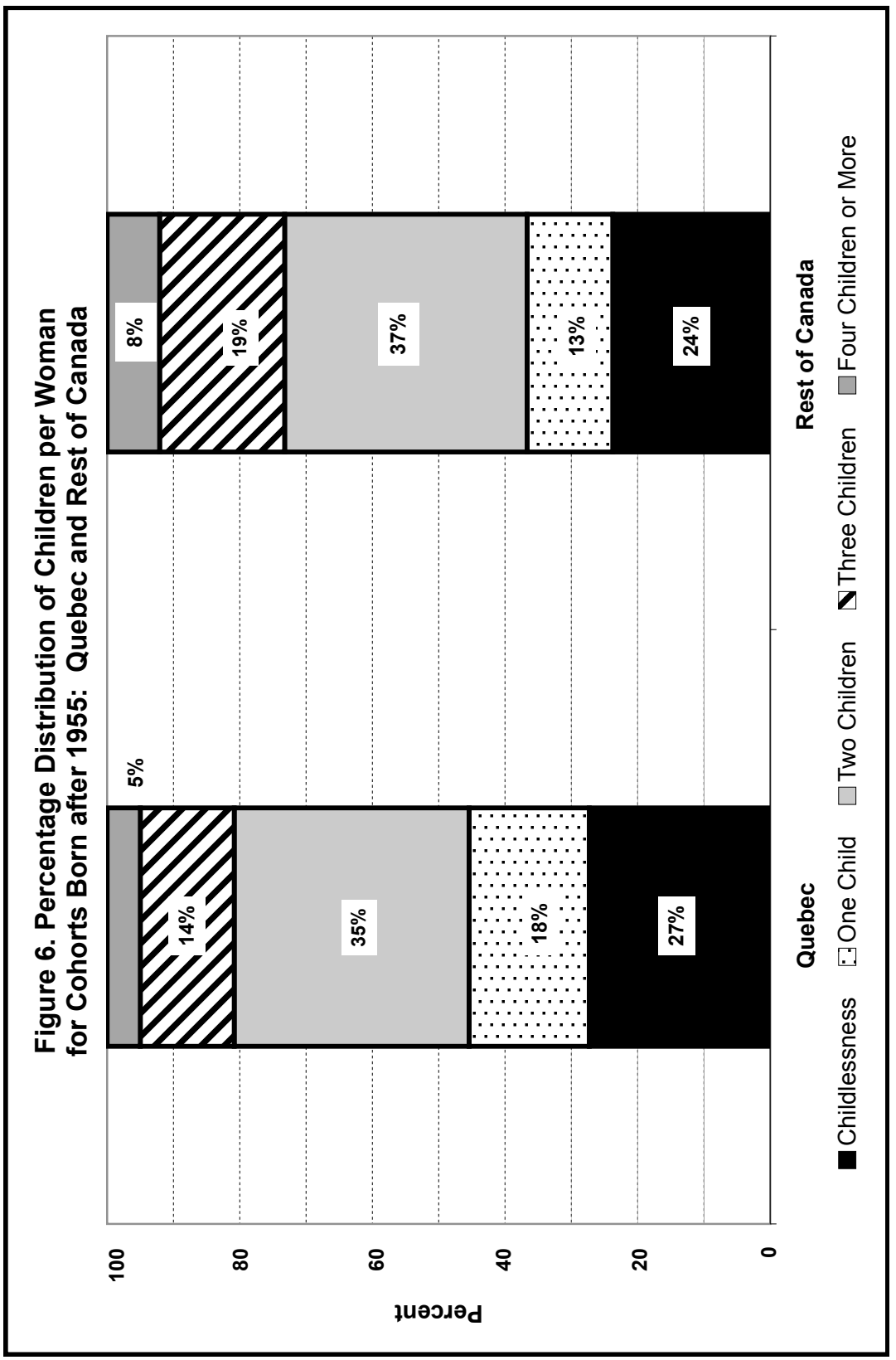

CSP 2010, 37.3-4: 339-373 


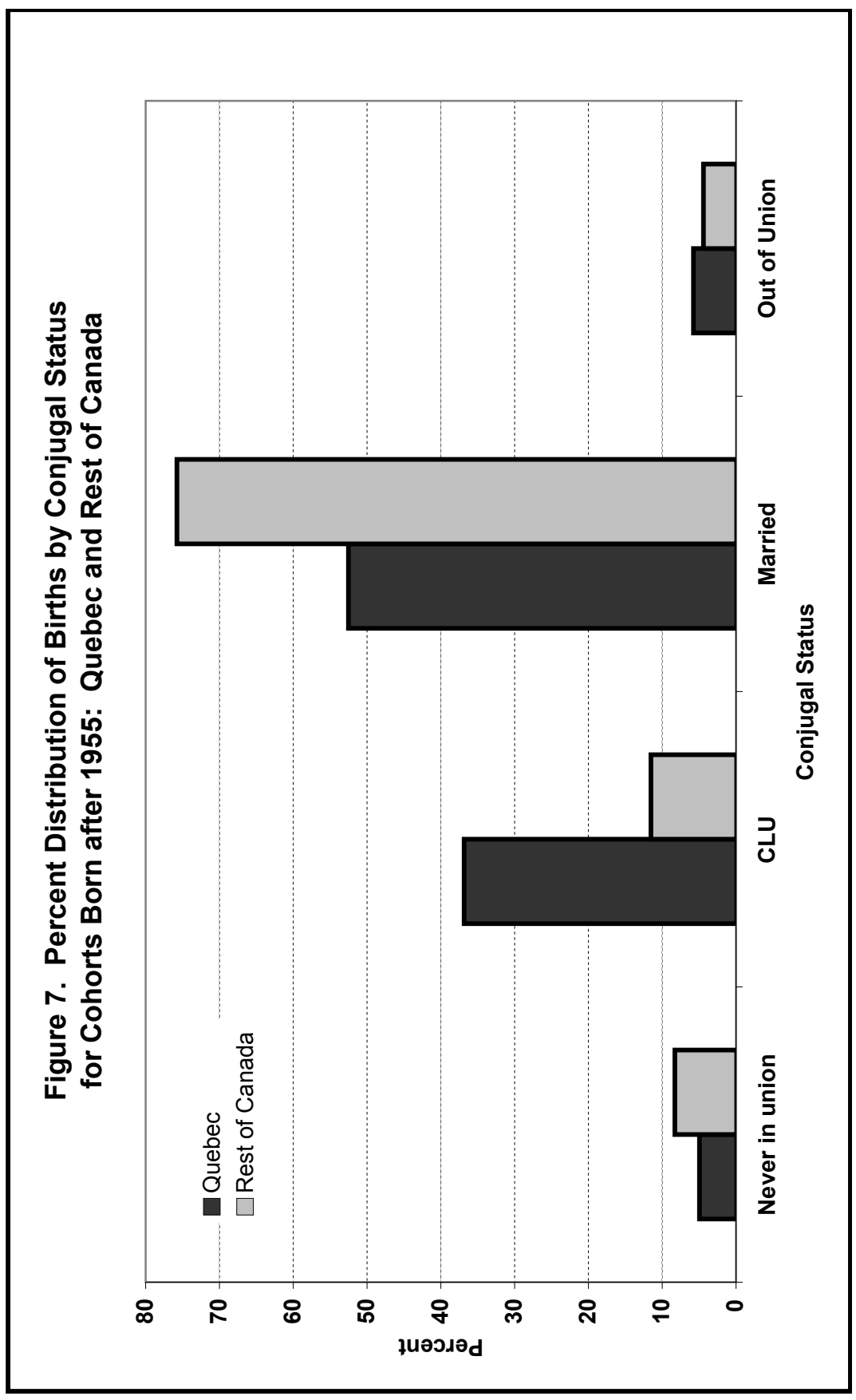

CSP 2010, 37.3-4: 339-373 
A Microsimulation Model to Study the Interaction between Fertility and Union Formation and Dissolution: An Applicatioin to Canada and Quebec

reproduction in Quebec, common-law unions still appear more as a trial period of living together before marriage in the rest of Canada (Bélanger and Dumas 1997).

Table 1 presents the distribution of births by conjugal status and birth rank. The percentage of births from single mothers is higher for the first birth and decreases constantly for higher birth ranks; this percentage is generally higher in the rest of Canada than in Quebec, particularly for first births where a 5\% difference exists. The fact that Quebec women enter into unions sooner and, consequently, spend less time in the risk group may explain this difference. As we have seen before, Canadian women outside Quebec give birth when they live in a common-law union much more infrequently, compared to women from Quebec. Generally, the proportion of births from common-law unions is higher for the first birth. In the Quebec cohort, $40 \%$ of first births take place in a commonlaw union, as well as about $33 \%$ of second and third births. In the rest of Canada, we observe the same declining pattern with birth order, but at much lower levels $(13 \%$ for first births in common-law unions and approximately $11 \%$ for births of higher ranks). It is possible that a certain number of couples decide to marry soon after the birth of their first child, decreasing the proportion of births of higher rank taking place in a common-law union and leading to a higher proportion of married women for births of higher rank. As expected, a majority of births of all ranks take place among married couples (except for the first birth in Quebec), but the proportion is higher for second and third births.

\section{Conjugal Status}

Table 2 presents the mean age at union formation and dissolution by type of union (marriage or common-law union) obtained from the simulation. First, comparing the average age at marriage and at common-law union, we observe that common-law unions generally take place earlier than marriages, independent of the union rank. On average, first unions by marriage take place at age 25.6 in both regions, while the first commonlaw unions occur at age 22.5 in Quebec and 23.3 in the rest of Canada. We observe small differences between average ages at marriage in the two regions, but for all union ranks, average ages at common-law unions are lower in Quebec that in the rest of Canada.

As well as occurring at a younger age than marriages, commonlaw unions are also less stable (Statistics Canada 2007). Therefore, as would be expected, the average age at union dissolution is much lower for common-law unions than for marriages. In both regions, the 


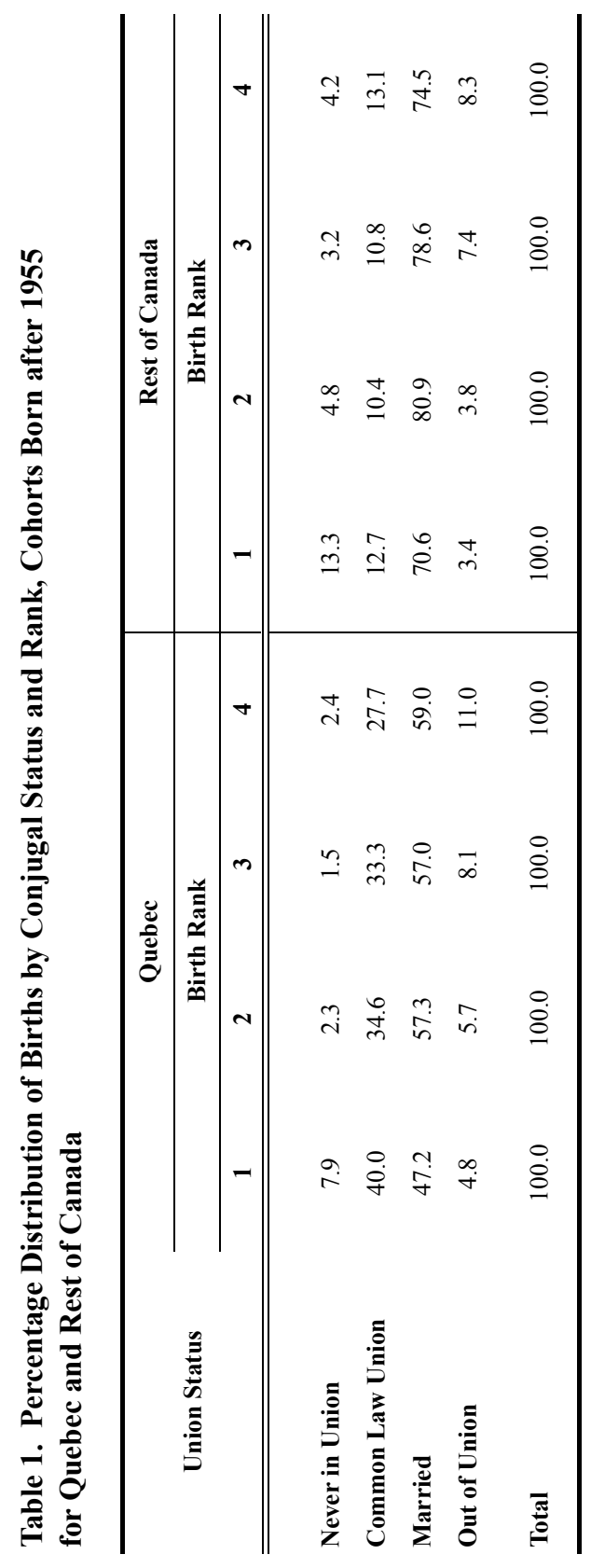

CSP 2010, 37.3-4: 339-373

360 
A Microsimulation Model to Study the Interaction between Fertility

and Union Formation and Dissolution: An Application to Canada and Quebec

Table 2

Average Ages at Union Formation and Dissolution, Cohorts Born after 1955 for Quebec and Rest of Canada

\begin{tabular}{lccc}
\hline \multicolumn{1}{c}{ Unions } & Quebec & $\begin{array}{c}\text { Rest of } \\
\text { Canada }\end{array}$ & Difference \\
\hline Marriages & & & \\
& & & \\
$1^{\text {st }}$ Union & 25.6 & 25.6 & 0.0 \\
$2^{\text {nd }}$ Union & 36.0 & 36.2 & -0.18 \\
$3^{\text {rd }}$ Union & 40.7 & 41.0 & -0.29 \\
$4^{\text {th }}$ Union & 41.6 & 43.3 & -1.66 \\
$1^{\text {st }}$ Separation & 34.2 & 34.9 & -0.72 \\
$2^{\text {nd }}$ Separation & 38.9 & 40.4 & -1.51 \\
$3^{\text {rd }}$ Seperation & 44.5 & 43.3 & 1.25 \\
& & & \\
Common Law Unions & & & \\
& & & -0.77 \\
$1^{\text {st }}$ Union & 22.5 & 23.3 & -2.01 \\
$2^{\text {nd }}$ Union & 32.3 & 34.3 & -1.65 \\
$3^{\text {rd }}$ Union & 38.6 & 40.2 & -0.72 \\
$4^{\text {th }}$ Union & 42.2 & 42.9 & -0.24 \\
$1^{\text {st }}$ Separation & 27.4 & 27.6 & -0.90 \\
$2^{\text {nd }}$ Separation & 36.1 & 36.8 & \\
$3^{\text {rd }}$ Separation & 40.5 & 41.4 & \\
& & & \\
\hline
\end{tabular}

common-law union, seven years younger than a separation from a first marriage. Similar results can be observed for second rank unions, but the age differences are smaller, probably because of different paths to the second union. The second common-law separation takes place two years younger in Quebec and almost four years younger in the rest of Canada than the dissolution of a second marriage.

With regards to differences between Quebec and the rest of Canada, it appears that Quebec women usually enter into unions slightly earlier than other Canadian women and this is particularly true for those entering common-law unions. For example, the average age at first common-law union of Quebec women is 22.5 years, three-quarters of a year earlier than women from the rest of Canada. This difference is larger for second and third common-law unions, again probably because of a 
larger proportion of Quebecers having had a first common-law union end prematurely. The difference in the average age at dissolution of commonlaw unions between the two groups is smaller than the average age of common-law unions, suggesting that common-law unions in Quebec are more stable than in the rest of Canada (Wu and Balakrishnan 1995). The average age at marriage for each union rank is also slightly lower in Quebec than in the rest of Canada. On the other hand, contrary to what we have seen with common-law unions, the difference in the average age at the dissolution of marriage between the two populations is greater than the average age at marriage, suggesting that marriages in the rest of Canada are more stable than they are in Quebec.

Women in Quebec start their conjugal life earlier but opt more often for the less stable common-law union than marriage. What is the effect of this choice on the average number of unions a woman can expect to have in both regions and on the average number of years lived in a conjugal union? Our simulation offers some answers to these two questions. On average, Quebecers have 1.53 unions during their reproductive years, 17 percent more than women from the rest of Canada who average 1.31 unions during the same age span.

Important differences also appear between the two populations when one compares the average number of years lived in each conjugal status in the simulated cohorts during their reproductive lives (Figure 8). First, because Quebecers enter into common-law unions at a younger age and in greater proportions, they also spend fewer years in the single state than women from the rest of Canada. Another important difference is the average duration in the married state. Canadian women residing outside Quebec were married on average for 15 of their 35 reproductive years, compared to just under 10 of 35 years for Quebec women. On the other hand, women in Quebec lived over eight of their reproductive years in common-law unions, compared to less than four years for women in the rest of Canada. Finally, because Quebecers are living fewer years in the single state, the models shows that they can also expect to live one additional year in the out of union state. Several studies have demonstrated that common-law unions were more frequent in Quebec than elsewhere in the country, but to our knowledge, this is the first estimation of a distribution of expected fertile life over time lived in each conjugal state. 


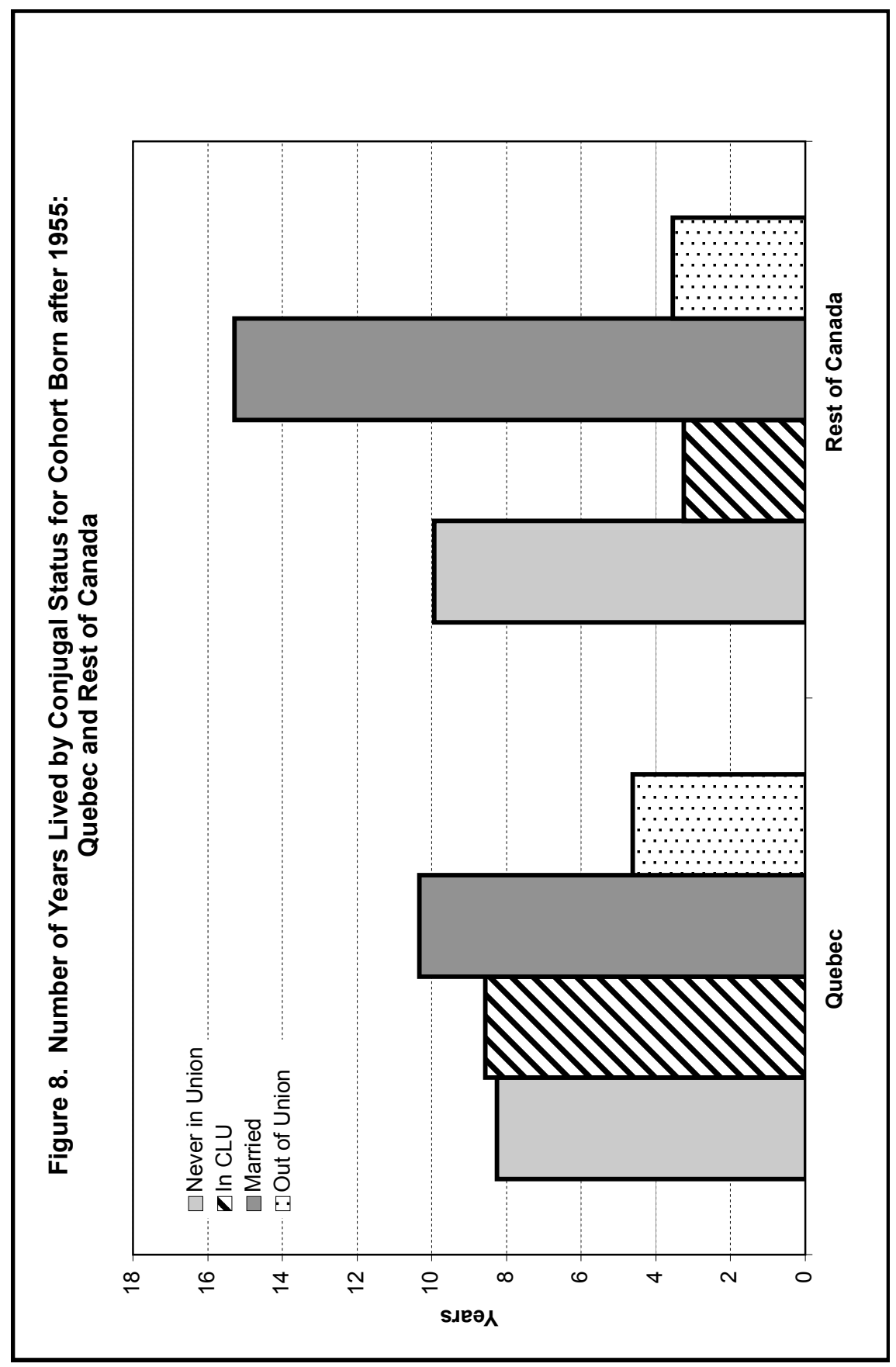

CSP 2010, 37.3-4: 339-373 


\section{Interaction between Conjugal Status and Fertility}

In order to determine the impact of union stability on the difference in completed fertility of the two populations, we simulated two additional scenarios. First, we computed the fertility of a population having Quebec's parameters of fertility and the rest of Canada's parameters for union formations and dissolutions. The second simulation was just the opposite--we computed the completed fertility of a population having Quebec's conjugal histories with the rest of Canada's parameters of fertility. The simulated completed fertility rates of those two populations as well as those of our two initial populations are found in the following table.

The difference in completed fertility between the two simulated populations is 0.25 children. When simulating Quebec conjugal histories with the fertility parameters of the rest of Canada, completed fertility is increased by 0.11 children per woman. Our simulation experiment reveals, therefore, that $44 \%$ of the difference in completed fertility of the two populations can be attributed to the difference in fertility behaviour. Simulating Quebec fertility with the parameters estimated from the conjugal history of the rest of Canada increased the completed fertility rate by 0.07 children or $28 \%$ of the difference. The remaining $28 \%$ of the difference in completed fertility of the two populations may be due to the interactions between the two sets of parameters.

Table 4 shows the number of women following the different conjugal paths in each region and the impact of different conjugal experiences on fertility. The type of union clearly has an important effect on the childbearing experiences of women; completed fertility is higher by about 0.5 children among women who only had marriages, compared to women who only had common-law unions. This finding remains valid, regardless of the number of unions or the region. With the exception of women having had three marriages (a group whose number is very small and for whom the estimation is imprecise), fertility does not increase with the number of unions. Completed fertility is highest among women having had only one marriage than for women having had any other type of conjugal history. This is an indication that the net effect of union instability is to reduce completed family size; it corroborates the finding of Thompson et al. (2009) for France. However, the negative effect of union instability on fertility (measured by the number of unions) is much smaller than the negative effect of choosing cohabitation over marriage as a type of union, an indication of the importance of taking the type of union into account.

The differences in fertility between Quebec and the rest of Canada are generally smaller when we control for the marital history of women. 
A Microsimulation Model to Study the Interaction between Fertility and Union Formation and Dissolution: An Application to Canada and Quebec

Lower completed fertility rates in Quebec again appear to be more a result of a compositional effect (fewer women opting for marriages and more for common- law unions) than of a differential in fertility among each group of women. We find negligible differences between regions among women having had only common-law unions and smaller differences among those having had only marriages than for the total population. More than three out of ten women in Quebec have had only common-law unions, compared to only one in ten in the rest of Canada. On the other hand, almost seven out of ten women in the rest of Canada have had only marriages, while the rate is just above four out of ten in Quebec.

Table 3

Completed Fertility for Cohorts Born after 1950

\begin{tabular}{lc}
\hline \multicolumn{1}{c}{ Population } & $\begin{array}{c}\text { Simulated Completed } \\
\text { Fertility }\end{array}$ \\
\hline Quebec & 1.65 \\
Quebec with Fertility Parameters of ROC & 1.76 \\
Quebec with Unions Parameters of ROC & 1.72 \\
& $\square 1.90$ \\
\hline
\end{tabular}

It is also interesting to note that the fertility of women having had exactly two unions (comprised of one marriage and one common-law union) is larger for women who first married and then formed a common-law union than for women who first had a common-law union followed by a marriage. This is probably due to the fact that the average duration of first common-law unions is much shorter than the average duration of first marriages. Women who married first are thus more likely to spend a larger number of their more fertile years in a union, compared to women who formed a common-law union first. In addition, re-partnering after a first dissolution is more rapid if the second union is a common-law union than if it is a marriage, which thus decreases the number of fertile years lived out of union. 


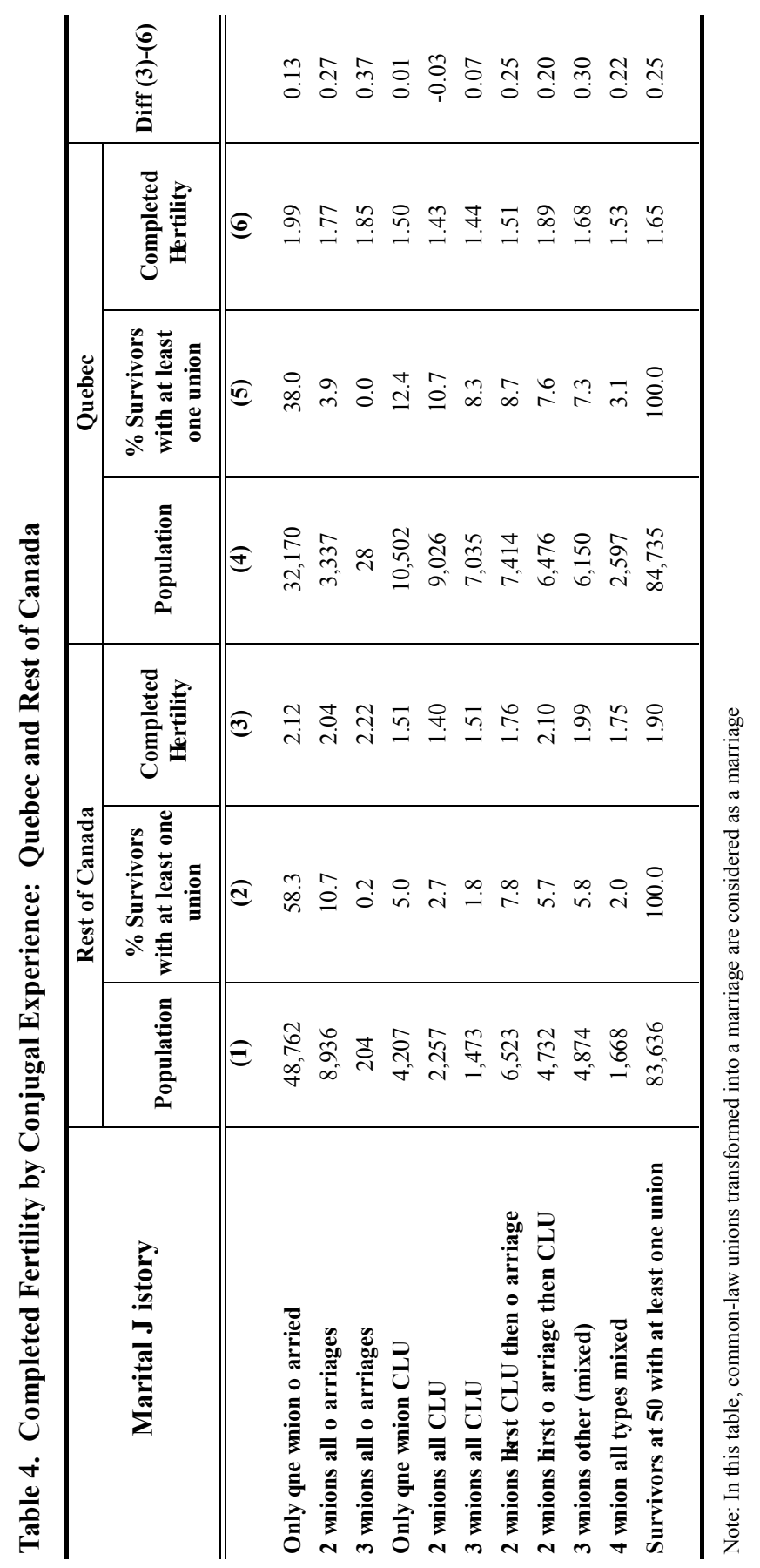


A Microsimulation Model to Study the Interaction between Fertility

and Union Formation and Dissolution: An Application to Canada and Quebec

The results shown in Table 5 support this interpretation. Table 5 shows the simulated completed fertility of women having had a first dissolution by parity, age at union dissolution and type of first union. As in Table 4, when we do not control for age at dissolution, the completed fertility is larger for women who had a common-law union first than for women who married first. When we control for age at dissolution, however, most of the differences between types of first union disappear. The number of married women having had a divorce increases with age at dissolution while the opposite is also true, i.e. the number of commonlaw women who had a dissolution decreases with age at dissolution. Since the number of additional births (completed fertility - parity at dissolution) also decreases with age at dissolution, the later the first union breakdown is experienced, the less fertile the next union could be. This is not surprising, considering that in our model, the risk of having a second union is only dependent on duration since separation and on whether or not the woman has previously had a child. The model distinguishes between union rank and type, but the risks of remarrying or forming a second common-law union are the same for all of those who have had a union dissolution, regardless of the type of first union. Possibly, people who have a first common-law union are more likely to enter into another common-law union than marriage, but the current model does not control for this. The number of additional births is also larger for lower parities at dissolution, particularly for childless women.

\section{Summary and Conclusion}

This paper is a first attempt to measure the impact of changes in conjugal relationships on fertility in Canada. It does so by means of a microsimulation model that integrates parameters of union formation, union dissolution and fertility estimated from marital and fertility histories of women living in Quebec versus in the rest of Canada. It takes into account differences in fertility by rank and by conjugal status, as well as the effect of having had a child on union formations and dissolutions. The model provides indicators that are often difficult or impossible to obtain from official statistics: distribution of women by parity, number of years lived in each conjugal status (including commonlaw unions) over the fertile period, and the distribution of births by conjugal status or individual conjugal histories. 
Table 5

Simulated Completed Fertility of Women having had a First Dissolution by Type, Age and Parity at First Dissolution for Quebec and Rest of Canada

\begin{tabular}{llcccc}
\hline & \multicolumn{5}{c}{ Status at Dissolution: Married } \\
\hline $\begin{array}{c}\text { Age at } \\
\text { Dissolution }\end{array}$ & Population & 0 & Parity at Dissolution & 3 \\
Quebec & & & & 2 & \\
& & & & & \\
$20-24$ & 2,484 & 1.36 & 1.67 & 2.38 & 3.28 \\
$25-29$ & 3,465 & 0.97 & 1.69 & 2.27 & 3.23 \\
$30-40$ & 6,378 & 0.45 & 1.40 & 2.18 & 3.17 \\
Total & 18,243 & 0.88 & 1.48 & 2.20 & 3.20 \\
& & & & & \\
Rest of Canada & & & & & \\
& & & & & \\
$20-24$ & 2,576 & 1.51 & 1.96 & 2.41 & 3.29 \\
$25-29$ & 4,617 & 1.22 & 1.91 & 2.39 & 3.25 \\
$30-40$ & 9,287 & 0.62 & 1.57 & 2.27 & 3.18 \\
Total & 24,456 & 0.98 & 1.65 & 2.27 & 3.21 \\
& & & & & \\
\hline
\end{tabular}

\begin{tabular}{lllccc}
\hline & & \multicolumn{3}{c}{ Status at Dissolution: Common-Law } \\
Union \\
\hline $\begin{array}{c}\text { Age at } \\
\text { Dissolution }\end{array}$ & Population & 0 & \multicolumn{4}{c}{$\begin{array}{c}\text { Parity at Dissolution } \\
\text { Quebec }\end{array}$} & & 1 & 3 & \\
& & & & & \\
$20-24$ & 10,257 & 1.40 & 1.75 & 2.32 & 3.36 \\
$25-29$ & 7,507 & 0.46 & 1.63 & 2.28 & 3.23 \\
$30-40$ & 6,534 & 0.10 & 1.19 & 2.20 & 3.19 \\
Total & 30,741 & 1.17 & 1.58 & 2.23 & 3.19 \\
& & & & & \\
Rest of Canada & & & & & \\
& & & & & \\
$20-24$ & 4,881 & 1.63 & 1.88 & 2.47 & 3.21 \\
$25-29$ & 4,073 & 1.22 & 1.76 & 2.36 & 3.14 \\
$30-40$ & 3,250 & 0.71 & 1.58 & 2.30 & 3.16 \\
Total & 14,775 & 1.36 & 1.73 & 2.34 & 3.21 \\
& & & & & \\
\hline
\end{tabular}


A Microsimulation Model to Study the Interaction between Fertility and Union Formation and Dissolution: An Applicatioin to Canada and Quebec

In this paper, we contrasted results in terms of cohort fertility and conjugal life of a cohort of women born after 1955 living in Quebec with another such cohort living in the rest of Canada. Their marital and fertility histories began in the early 1970's when differences in fertility and conjugal life began to diverge between the two regions with a more rapid decline in fertility and a larger increase in common-law unions in Quebec. In both regions, these changes were progressive over time, affecting different cohorts differently.

Results show that about one-quarter of the women from the cohorts born after 1955 remain childless, a proportion that is slightly larger in Quebec than in the rest of Canada. A significantly larger proportion of Quebecers also have only one child. In the context of an aging population, this might mean that the future availability of informal care to the elderly will be scarcer in Quebec, compared to the rest of Canada.

Another interesting result is the percentage of births taking place in couples either living in common-law unions or out of a union. In the simulated cohorts, nearly $37 \%$ of births occurring in Quebec take place in common-law unions as compared to $11 \%$ for women in the rest of the country, while the proportion of births to women not living with their child's father is slightly higher in the rest of Canada (13\% compared to $11 \%$ in Quebec). This affects the proportions of lone-parent families in the two regions.

Future enhancements to the simulation model that add links between children and their mothers, or that model the departure from the parental home can help in the projection of future lone-parent families. Another potential enhancement to the model is the addition of a parameter that accounts for the period effect on conjugal and birth transitions. Such an enhancement would help to shed light on the effects of interactions between conjugal life and fertility over time in addition to the regional differences illustrated in this paper.

\section{Acknowledgement}

We are thankful to Andrew MacLeod for his language editing of this paper. Responsibility for any errors rests with the authors. 


\section{End Notes}

1. Except for the fourth union where this proportion was $20 \%$; however, the sample size was very small, with only 66 women at risk.

2. RiskPaths is a documented teaching model, created using the Modgen programming language that has been incorporated into many prior training courses throughout Europe and North America. The model can be downloaded from Statistics Canada's website through the link: http://www.statcan.gc.ca/micr osimulation/modgen/download-telecharger-eng.htm

3. The Modgen language has been used to create several diverse microsimulation models over the past fifteen years. An overview of these models is available from Statistics Canada's website through th link: http://www.statcan.gc.ca/microsimulation/modge n/new-nouveau/mods/mods-eng.htm

4. After linear extrapolation of age-specific fertility rates for the cohorts that have not reached age 50 in 2004.

\section{References}

Balakrishnan, T. R., E. Lapierre-Adamcyk, and K. J. Krotki. 1993. Family and Childbearing in Canada: A Demographic Analysis. Toronto: University of Toronto Press.

Beaupré, P. and E. Cloutier. 2007. Navigating Family Transitions: Evidence from the General Social Survey. Statistics Canada Cat no. 89-625, Ottawa, Canada.

Bélanger, A. and J. Dumas. 1997. Common-law unions in Canada at the end of the $20^{\text {th }}$ century in Report on the Demographic Situation in Canada. Statistics Canada Cat. No. 91-209. Ottawa: Statistics Canada, pp. 123-186.

Bélanger, A. 2006. Report on the Demographic Situation in Canada, 2003-2004. Cat. No. 91-209. Ottawa: Statistics Canada. 
A Microsimulation Model to Study the Interaction between Fertility and Union Formation and Dissolution: An Applicatioin to Canada and Quebec

Bélanger, A. and P. Turcotte. 1999. L'influence des caractéristiques sociodémographiques sur le début de la vie conjugale des Québécoises. Cahier québécois de démographie 28(1-2): 173-197.

Belliveau, J., J. Oderkirk, et al. 1994. Common-law unions. The Quebec difference. Canadian Social Trends 33: 8-12.

Bongaarts, J. 1978. A Iramework for Dhalyzing the Sroximate of Ceterminants of Iertility. Population and Development Review 4(1): 105-132.

Cox, D. R. 1972. Regression models and life-tables. Journal of the Royal Statistical Society 8(34): 187-220.

Dumas, J. and Y. Péron. 1992. Marriage and Conjugal Life in Canada. Cat. No. 91-534. Ottawa: Statistics Canada.

Girard, C. 2008. Le bilan démographique du Québec. Institut de la statistique du Québec. Québec, Canada.

Juby, H., N. Marcil-Gratton and C. Le Bourdais. 2004. The Impact of Parents' Family Transitions on Children's Family Environment and Economic Well-Being: A Longitudinal Assessment. Department of Justice Canada. Research Report 2004-FCY-6E. Ottawa, Canada. http://www.justice.gc.ca/eng/pi/pad-rpad/reprap/2004 6/index.html (retrieved on April 2008).

Korn, E. L. and B. I. Graubard. 1999. Analysis of Health Survey. Wiley Series in Probability and Statistics. New York: John Wiley

Lapierre-Adamcyk, E. and C. Charvet. 1999. L'union libre et le mariage : un bilan des travaux en démographie. Cahiers québécois de démographie. 28(1-2): 1-21.

Lapierre-Adamcyk, E., C. Le Bourdais and N. Marcil-Gratton. 1999. Vivre en couple pour la première fois: la signification du choix de l'union libre au Québec et en Ontario. Cahiers québécois de démographie 28(1-2): 199-227.

Laplante, B. 2004. The diffusion of cohabitation in Québec and Ontario and the power of norms in religion. The Canadian Journal of Sociology 31(1): 1-24. 
Le Bourdais, C., G. Neill, and N. Marcil-Gratton. 2000. L'effet du type d'union sur la stabilité des familles dites " intactes. Recherches Sociographiques 41: 53-74.

Le Bourdais, C. and N. Marcil-Gratton. 1996. Family transformations across the Canadian/American border; When the laggard becomes the leader. Journal of Comparative Family Studies 27(3): 415-436.

Le Goff, J.-M. 2003. Modélisation des événements du parcours de vie. Une introduction. http://www2.unil.ch/pavie/documentation/int roduction.html

Loomis, L. S. and N. S. Landale. 1994. Nonmarital cohabitation and childbearing among black and white American women. Journal of Marriage and the Family 56: 949-962.

Manning, W. D. 1995. Cohabitation, marriage, and entry into motherhood. Journal of Marriage and the Family 57: 191-200.

Romaniuc, A. 1984. Fertility in Canada: From Baby-Boom to BabyBust. Cat. No. 91-524. Ottawa: Statistics Canada.

Spielauer, M., E. Koytcheva, D. Kostova. 2007. First and second births in first and second unions: a decomposition of fertility decline in Bulgaria and Russia since the 1989 economic and political transition. Max Planck Institute for Demographic Research, Germany, WP 2007-001.

Statistics Canada. 2007. Modgen Developer's guide. Ottawa: Statistics Canada. http://www.statcan.gc.ca/microsimulation/pdf/devguide-eng.pdf

Statistics Canada. 2008. Report on the demographic Situation in Canada, 2005-2006. Cat. No. 91-209. Ottawa: Statistics Canada.

Statistics Canada. 2006. Report on the demographic Situation in Canada, 2003-2004. Cat. No. 91-209. Ottawa: Statistics Canada.

Statistics Canada. 2002. Changing conjugal life in Canada. Catalogue no. 89-576-XIE. Ottawa: Statistics Canada. 
A Microsimulation Model to Study the Interaction between Fertility and Union Formation and Dissolution: An Applicatioin to Canada and Quebec

Thomson, E., M. Winkler-Dworak, M. Spielauer, and A. Prskawetz. 2009. Union Instability as an Engine of Fertility? A Microsimulation Model for France. Vienna Institute for Demography Working Paper 200902

http://www.oeaw.ac.at/vid/download/WP2009 02.pdf

Wu, Z. 1996. Childbearing in cohabitational relationships. Journal of Marriage and the Family 58(2): 281-292.

Wu, Z. 1995. The stability of cohabitation relationship: The role of children. Journal of Marriage and the Family 57(1): 231-236.

Wu, Z. and T. R. Balakrishnan. 1995. Dissolution of premarital cohabitation in Canada. Demography 32(4): 521-532. 